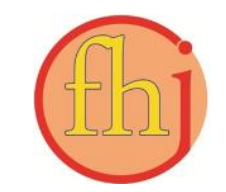

Faletehan Health Journal, 8 (1) (2021) 42-50

www. journal.Ippm-stikesfa.ac.id/ojs/index.php/FHJ

ISSN 2088-673X | e-ISSN 2597-8667

\title{
Gambaran Pengetahuan, Sikap, dan Tingkat Kecemasan Masyarakat tentang Kejadian Covid-19 di Lingkungan Perumahan Taman Banten Lestari Kota Serang Tahun 2020
}

\author{
Ghina Salsa Bela ${ }^{1 *}$, Lenny Stia Pusporini ${ }^{1}$, Nila Marwiyah ${ }^{1}$, Bambang Kuntarto ${ }^{1}$ \\ ${ }^{1}$ Universitas Faletehan, Serang \\ *Corresponding Author: ghinasls98@gmail.com
}

\begin{abstract}
Abstrak
Penyakit Coronavirus Disease (Covid-19) menyebar luas dan cepat ke beberapa negara di dunia, menyebabkan terjadi peningkatan jumlah orang yang terinfeksi oleh Covid-19 setiap harinya. Tujuan penelitian ini untuk mengetahui bagaimana gambaran pegetahuan, sikap dan tingkat kecemasan masyarakat tentang kejadian Covid-19 di lingkungan Perumahan Taman Banten Lestari pada tahun 2020. Penelitian ini merupakan jenis penelitian deskripsi observasional. Objek penelitian ini adalah masyarakat yang tinggal di lingkungan Perumahan Taman Banten Lestari Blok D RW 21. Teknik pengambilan sampel dalam penelitian ini menggunakan purposive sampling, dengan jumlah responden sebanyak 84 orang. Hasil penelitian berdasarkan deskriptif frekuensi menunjukan sebagian besar responden (53,6\%) memiliki pengetahuan baik, sebagian besar responden (54.8\%) memiliki sikap positif dan sebagian besar responden (67,9\%) memiliki kecemasan ringan. Petugas kesehatan sebaiknya memberikan penyuluhan tentang Covid-19 kepada masyarakat, sehingga dapat meningkatkan pengetahuan, sikap positif dan menurunkan tingkat kecemasan masyarakat, sehingga masyarakat lebih waspada terhadap kejadian Covid-19.
\end{abstract}

Kata Kunci: Pengetahuan Masyarakat, Sikap Masyarakat, Tingkat Kecemasan Masyarakat, Covid-19

\section{The Depiction of Public Knowledge, Attitudes and Anxiety Level Regarding Covid- 19 Occurrence at Taman Banten Lestari Residence in 2020}

\begin{abstract}
Coronavirus Disease (Covid-19) is spreads widely and rapidly to several countries of the world, resulting in an increased number of people infected by Covid-19 every day. The purpose of this study was to identify the depiction of public knowledge, attitudes and anxiety level regarding Covid-19 occurrence at Taman Banten Lestari Residence in 2020. The study design used was observational description with number of subject were the communities who live in Taman Banten Lestari Residence Block D RW 21. The sampling technique was purposive sampling, with total 84 respondents. The frequency descriptive-based research result showed that most of respondent (53.6\%) had a good knowledge, (54.8\%) had a positive attitude and (67.9\%) had a mild anxiety. Health workers should continually educate public about Covid19 to improve knowledge, positive attitude and to decrease the level of anxiety of community, so that people are more alert to Covid-19 occurrence.

Keywords: Public Knowledge, Public Attitudes, The Level of Public Anxiety, Covid-19
\end{abstract}


Faletehan Health Journal, 8 (1) (2021) 42-50

\section{Pendahuluan}

Masyarakat di beberapa negara saat ini sedang mengalami kekhawatiran karena peningkatan jumlah pasien yang dikonfirmasi terkena wabah penyakit Covid-19 (Lee, 2020). Covid-19 merupakan keluarga besar virus yang dapat menyebabkan penyakit pada manusia dan hewan. Penyakit ini pada manusia dapat menyebabkan infeksi saluran pernafasan, bahkan penyakit ini dapat timbul mulai dari flu biasa sampai penyakit yang serius seperti Middle East Respiratory Syndrome (MERS) dan Sindrom Pernafasan Akut Berat/ Severe Acute Respiratory Syndrome (SARS) (Kemenkes RI, 2020).

Seluruh masyarakat yang ada di dunia dalam beberapa bulan terakhir digemparkan dengan meluasnya wabah epidemik virus baru disebut Covid-19, telah terjadi di Wuhan, Cina. Kasus pertama terjadi pada awal Desember 2019 dan pada tanggal 29 Januari 2020, lebih dari 7000 kasus telah dilaporkan di Tiongkok. Laporan awal menyarankan bahwa penularan Covid-19 dapat terjadi dari orang yang menular, yang belum menunjukkan gejala (Liu, Pierre, Ousmane dan Glenn, 2020).

WHO memberi nama virus baru tersebut Sever acute respiratory syndrome coronavirus- 2 (SARS-CoV-2) dan nama penyakitnya sebagai Covid-19. Jumlah kasus Covid-19 di dunia setiap hari nya terus bertambah, menurut data WHO pada tanggal 22 Maret ditemukan 267.013 kasus, 11.201 jiwa meninggal, dan terdapat 185 negara atau wilayah yang teridentifikasi kasus Covid-19 (WHO, 2020). Virus ini menyebar dengan cepat ke seluruh Cina selama Tahun Baru Cina. Kasus Covid-19 pertama kali terkonfirmasi di China sebanyak 425 kasus, dengan usia rata-rata adalah 59 tahun, dan 56\% dari kasus yang dikonfirmasi adalah laki-laki (Li et al, 2020).

Menurut data WHO kasus Covid-19 pertama kali teridentifikasi di Indonesia pada tanggal 2 Maret 2020 dengan jumlah kasus terinfeksi 2 orang. Jumlah terus bertambah setiap hari nya, diketahui menurut data per tanggal 25 Maret 2020 terdapat 790 kasus positif, 31 sembuh dan 58 orang meninggal dunia, dan dalam satu bulan tepat nya tanggal 25 April 2020 terdapat 8.607 kasus positif, 1.042 sembuh dan 720 meninggal dunia (Kemenkes RI, 2020). Kenaikan angka kejadian kasus Covid-19 ini begitu cepat dan signifikan sejak pertama kali teridentifikasi virus tersebut masuk ke Indonesia.

Menurut data Dinas Kesehatan Provinsi Banten pada tanggal 25 April 2020 kasus terkonfirmasi ada 304 kasus positif, 52 orang sembuh dan 43 orang meninggal dunia. Di Kota Serang sendiri pada tanggal 25 April 2020 orang dalam pemantauan (ODP) ada sebanyak 313 orang, pasien dalam pengawasan (PDP) sebanyak 10 orang, kasus terkonfirmasi ada 3 kasus positif dan 1 orang meninggal dunia. Data ini dapat mengalami perubahan seiring dengan bertambahnya kasus Covid-19, naik turun nya data ini tergantung dari kerjasama semua pihak, baik masyarakat, pemerinah dan tim medis.

Gejala Covid-19 termasuk demam, batuk, lelah, hidung tersumbat, sakit tenggorokan, dan pilek. Satu dari enam orang yang mendapat Covid19 akan mengalami kesulitan bernapas. Orang yang lebih tua dan mereka yang memiliki masalah medis mendasar seperti masalah jantung tinggi atau diabetes lebih mungkin mengembangkan penyakit serius. WHO merekomendasikan bahwa orang dengan demam, batuk dan kesulitan bernapas harus mencari perhatian medis (Ryalino, 2020).

Penularan dari Covid-19 ini adalah melalui tetesan kecil (droplet) yang dikeluarkan oleh seseorang pada saat batuk ataupun bersin. Banyak orang yang telah teridentifikasi positif Covid-19 yang hanya memiliki gejala ringan saja seperti batuk ringan, bahkan ada yang tidak mengeluhkan sakit. Kondisi ini dapat saja terjadi pada tahap awal penyakit dari Covid-19 (Kemenkes RI, 2020). Populasi yang paling berisiko adalah orang-orang dengan fungsi kekebalan yang buruk seperti orang tua dan mereka yang mengalami disfungsi ginjal dan hati. (Adhikari et al, 2020). Cara yang paling efektif untuk melindungi diri sendiri dan orang lain terhadap Covid-19 ini yaitu dengan membersihkan tangan (personal hygine), saat batuk menutupi dengan tangan atau tisu, serta menjaga jarak terdahap orang lain sejauh 1 meter (3 kaki) dari seseorang yang batuk ataupun bersin (WHO, 2020).

Pasien Covid-19 meningkat pesat di seluruh dunia, sehingga menimbulkan kecemasan dan kekhawatiran publik di berbagai daerah. Kecemasan dan kekhawatiran seperti itu dapat meningkat karena kesalahan persepsi di masyarakat, ketakutan dan stigma terhadap epidemik Covid-19 dapat menyebabkan presepsi 
negatif terhadap pengendalian penyakit tersebut. Untuk merancang program antistigma yang efektif untuk mematahkan salah persepsi dalam Covid-19, dengan meningkatkan pengetahuan publik tentang kejadian Covid-19, dan menyebarkan pesan-pesan yang positif dan mendukung program pencegahan Covid-19 yang telah dirancang dengan menggunakan media sosial, mengingat tingkat akses yang tinggi di media sosial. Dengan informasi dan pengetahuan yang benar yang telah diposting di media sosial, diharapkan rasa takut dan stigma masyarakat cenderung diturunkan. Dengan mendorong penyediaan layanan kesehatan untuk memerangi informasi Covid-19 yang salah, stigma, dan rasa takut (Lin, 2020).

Berita di media sosial terkait Covid-19 di masyarakat masih simpang siur dan berisi berita yang tidak dapat di percaya (hoaxs), hal ini menimbulkan keresahan di masyarakat. Terdapat beberapa berita hoaxs yang telah disimpulkan oleh Kementrian Komunikasi dan Informatika RI (KOMINFO) tahun 2020 dengan judul artikel yang beredar terdiri dari penemuan virus corona pada tisu toilet, minum alkohol bisa kurangi risiko terkena corona, foto penampakan wujud virus corona setelah diperbesar 2600 kali, menteri kabinet jokowi positif terpapar Covid - 19. Serta masih banyak berita-berita hoaxs lainnya yang beredar.

Tugas sebagai profesional medis untuk memberikan informasi yang jujur dan ilmiah tentang apa yang kita ketahui, dan apa yang belum kita ketahui, tentang virus ini. Kita mungkin tidak dapat mencegah pandemi ini, tetapi kita tentu dapat mendidik masyarakat, terutama mereka yang tinggal di sekitar kita, untuk menghentikan rantai informasi yang tidak akurat ini menyebar lebih banyak (Lin, 2020).

Hasil studi pendahuluan yang diperoleh dari wawancara kepada 15 orang masyarakat yang tinggal di lingkungan Perumahan Taman Banten Lestari, sebagian besar masyarakat merasa cemas akan peningkatan jumlah pasien positif Covid-19. Rata-rata sumber informasi yang di dapat oleh masyarakat berasal dari media sosial, masyarakat beranggapan bahwa berita hoaks saat ini yang marak beredar di media sosial hanya membuat masyarakat lebih panik dan sangat meresahkan. Berdasarkan uraian masalah diatas, maka peneliti tertarik untuk melakukan penelitian yang berjudul "Gambaran pengetahuan, sikap dan tingkat kecemasan masyarakat tentang kejadian Covid-19 di lingkungan Perumahan Taman Banten Lestari”.

\section{Metodologi Penelitian}

Jenis penelitian yang digunakan dalam penelitian ini adalah deskriptif observasional. Populasi pada penelitian ini masyarakat yang tinggal di lingkungan Perumahan Taman Banten Lestari Blok D RW.21 dengan jumlah $310 \mathrm{KK}$ (Kartu Keluarga) dan didapatkan 84 sampel menggunakan Teknik purposive sampling. Penetapan sampel dengan cara memilih sampel diantara populasi sesuai dengan yang dikehendaki peneliti, sehingga sampel tersebut dapat mewakili karakteristik populasi tersebut. Penelitian ini dilaksanakan pada bulan Maret sampai Juli 2020, sementara pengambilan data dilakukan pada tanggal 18 Mei 2020 dengan menggunakan kuesioner melalui google form. Google form ini berisi kuesioner pengetahuan masyarakat tentang Covid-19, sikap masyarakat tentang Covid-19, dan bagaimana tingkat kecemasan masyarakat tentang Covid-19.

\section{Hasil dan Pembahasan}

1. Distribusi Frekuensi Tingkat Pengetahuan Masyarakat Tentang Covid-19 di Lingkungan Perumahan Taman Banten Lestari RW.21 Tahun 2020

\section{Tabel 1. Distribusi Frekuensi Tingkat Pengetahuan Responden di Lingkungan Perumahan Taman Banten Lestari RW.21}

\begin{tabular}{ccc}
\hline Pengetahuan & f & \% \\
\hline Kurang & 39 & 46,4 \\
\hline Baik & 45 & 53,6 \\
\hline Total & 84 & 100
\end{tabular}

Sumber: Data Primer, 2020

Berdasarkan tabel 1 hasil analisa univariat berdasarkan karakteristik tingkat pengetahuan responden dari total 84 responden di peroleh data hampir sebagian besar masyarakat yang memiliki pengetahuan baik tentang Covid -19 sebanyak 45 responden (53,6\%). Penentuan tingkat pengetahuan responden diambil berdasarkan nilai mean. Pengetahuan kurang jika nilai pengetahuan $<$ nilai mean $(15,76)$ dan pengetahuan baik jika nilai pengetahuan $>$ nilai mean $(15,76)$. 
Faletehan Health Journal, 8 (1) (2021) 42-50 www. journal.Ippm-stikesfa.ac.id/ojs/index.php/FHJ ISSN 2088-673X | 2597-8667

Tabel 2. Distribusi Frekuensi Karakteristik Responden Berdasarkan Sumber Informasi Yang Didapat di Lingkungan Perumahan Taman Banten Lestari RW.21

\begin{tabular}{lcc}
\hline $\begin{array}{c}\text { Sumber Informasi } \\
\text { Responden }\end{array}$ & f & \% \\
\hline Media Suara & 37 & 44 \\
Media Cetak & 1 & 1,2 \\
Media Sosial & 43 & 51,2 \\
Petugas Kesehatan & 3 & 3,6 \\
\hline
\end{tabular}

Sumber: Data Primer, 2020

Tingkat pengetahuan masyarakat di lingkungan Perumahan Taman Banten Lestari khususnya di RW.21 sebagian besar memiliki pengetahuan baik tentang Covid-19, di lihat dari jawaban kuesioner yang telah di sebar bahwa sebanayak 43 responden $(51,2 \%)$ cukup berperan aktif dalam memperoleh informasi yang ada dengan memanfaatkan penggunaan smartphone seperti whatsapp, instagram, twitter, facebook, google dan lainnya dalam proses pencarian informasi dengan baik, terlihat dari jawaban responden yang menunjukan bahwa sebagian besar responden memilih media sosial sebagai sumber informasi untuk mengenali penyakit Covid-19. Tingkat pengetahuan di Ngronggah Jawa Timur Tahun 2020 juga sama sebagian besar masyarakat memiliki pengetahuan baik tentang Covid-19 sebanyak 43 responden $(69,35 \%)$ (Sari, Nabila dan Atiqoh, 2020).

Pengetahuan seseorang atau responden mengenai kesehatan juga dapat dibentuk dari berbagai media melalui televisi, koran, radio dan media sosial serta diberikan penyuluhan yang intensif dari petugas kesehatan puskesmas setempat. Hal ini didukung dengan alasan masyarakat yang menggunakan internet melalui smartphone sebagai media informasi dalam mengenali pemahaman tentang kejadian Covid-19 lebih mudah memperoleh dari internet.

Media sosial menjadi sumber informasi yang paling banyak digunakan responden dalam memahami penyakit Covid-19. Media sosial yang digunakan oleh masyarakat pada penelitian ini adalah facebook, whatsapp, twitter, karena seiring dengan berkembanganya teknologi, maka mengakses hal apapun akan semakin mudah menggunakan internet, jangkauan untuk mencapai informasinya pun sangat luas (Lin, 2020).

Indikator utama pemahaman mengenai suatu penyakit adalah mengetahui gejala dan penyebabnya agar upaya pencegahan dapat dilakukan lebih awal sehingga tidak menimbulkan dampak yang lebih besar (Rahma, Kuswandewi, dan Chrysanti, 2016). Berdasarkakan jawaban responden pada kuesioner yang telah di bagikan oleh peneliti sebanyak $36(42,9 \%)$ responden tidak mengetahui bahwa obat antibiotik tidak efektif dalam mengobati Covid-19 dan sebanyak 25 $(29,8 \%)$ responden tidak mengetahui ada berapa langkah cuci tangan yang baik dan benar.

Masyarakat saat ini banyak yang memiliki pemahaman yang kurang tepat mengenai penyebab penyakit sehingga dapat menimbulkan persepsi masyarakat yang kurang tepat terhadap penyakit dan dapat mempengaruhi perilaku penangangan penyakit tersebut. Dengan pengetahuan yang baik tentang Covid-19 di harapkan masyarakat dapat melakukan penanganan dan pencegahan terhadap kejadian Covid-19 saat ini.

2. Distribusi Frekuensi Sikap Masyarakat Tentang Covid-19 di Lingkungan Perumahan Taman Banten Lestari RW.21 Tahun 2020

Tabel 4. Distribusi Frekuensi Berdasarkan Sikap Responden di Lingkungan Perumahan Taman Banten Lestari RW.21

\begin{tabular}{lcc}
\hline \multicolumn{1}{c}{ Sikap } & f & \% \\
\hline Negatif & 38 & 45,2 \\
\hline Positif & 46 & 54,8 \\
\hline Total & 84 & 100 \\
\hline
\end{tabular}

Sumber: Data Primer, 2020

Berdasarkan tabel 2 hasil analisa univariat berdasarkan karakteristik sikap responden dari total 84 responden di peroleh data hampir sebagian besar masyarakat yang memiliki sikap positif tentang Covid-19 sebanyak 46 responden (54.8\%). Penentuan sikap responden diambil berdasarkan nilai mean. Sikap negatif jika nilai sikap < nilai mean $(51,01)$ dan sikap positif jika nilai sikap > nilai mean $(51,01)$. 
Faletehan Health Journal, 8 (1) (2021) 42-50

www. journal.Ippm-stikesfa.ac.id/ojs/index.php/FHJ

ISSN 2088-673X | 2597-8667

Tabel 3. Distribusi Frekuensi Kuesioner Pengetahuan Responden di Lingkungan Perumahan Taman Banten Lestari RW.21

\begin{tabular}{|c|c|c|c|c|c|}
\hline \multirow{2}{*}{ No } & \multirow{2}{*}{ Kuesioner Pengetahuan } & \multicolumn{2}{|c|}{ Frekuensi } & \multicolumn{2}{|c|}{$\%$} \\
\hline & & Benar & Salah & Benar & Salah \\
\hline 1. & $\begin{array}{l}\text { Virus SARS dan MERS merupakan keluarga virus dari Covid- } \\
19 ?\end{array}$ & 53 & 31 & 63.1 & 36.9 \\
\hline 2. & Kasus Covid-19 pertamakali ditemukan dinegara? & 84 & 0 & 100.0 & 0 \\
\hline 3. & Bagaimana penyebaran virus Covid-19? & 75 & 9 & 89.3 & 10.7 \\
\hline 4. & $\begin{array}{l}\text { Berapa lama waktu yang diperlukan sejak tertular/terinfeksi } \\
\text { hingga muncul gejala penyakit infeksi Covid-19? }\end{array}$ & 82 & 2 & 97.6 & 2.4 \\
\hline 5. & $\begin{array}{l}\text { Apakah obat antibiotik efektif dalam mencegah dan mengobati } \\
\text { Covid-19? }\end{array}$ & 48 & 36 & 57.1 & 42.9 \\
\hline 6. & $\begin{array}{l}\text { Berapakah minimal jarak yang telah direkomendasikan oleh } \\
\text { World Health Organization (WHO) dalam upaya pencegahan } \\
\text { Covid-19? }\end{array}$ & 81 & 3 & 96.4 & 3.6 \\
\hline 7. & $\begin{array}{l}\text { Saat kita melakukan aktivitas pergi kepasar, naik transportasi } \\
\text { umum, dan makan diluar rumah, maka posisi kita ada pada } \\
\text { tingkat? }\end{array}$ & 48 & 36 & 57.1 & 42.9 \\
\hline 8. & $\begin{array}{l}\text { Saat kita dalam aktivitas pertemuan kelompok, arisan dan pergi } \\
\text { keluar negeri, maka posisi kita ada pada tingkat? }\end{array}$ & 78 & 6 & 92.9 & 7.1 \\
\hline 9. & Ada berapa langkah dalam cuci tangan yang baik dan benar? & 59 & 25 & 70.2 & 29.8 \\
\hline 10. & Saat mencuci tangan bisa menggunakan? & 81 & 3 & 96.4 & 3.6 \\
\hline 11. & $\begin{array}{l}\text { Orang yang memiliki riwayat berkunjung/tinggal didaerah } \\
\text { penularan Covid-19, pernah berkontak langsung dengan } \\
\text { seseorang yang terjangkit/terkonfirmsi Covid-19. Setelah itu, } \\
\text { orang tersebut meliliki ganggungan saluran pernafasan } \\
\text { (deman, batuk, pilek, sesak nafas dan disertai gejala lainnya) } \\
\text { merupakan? }\end{array}$ & 52 & 32 & 61.9 & 38.1 \\
\hline 12. & $\begin{array}{l}\text { Orang yang memiliki gejala demam atau gangguan saluran } \\
\text { pernafasan ringan, dan pernah mengunjungi/tinggal di daerah } \\
\text { yang diketahui merupakan daerah penularan Covid-19, } \\
\text { merupakan? }\end{array}$ & 62 & 22 & 73.8 & 26.2 \\
\hline 13. & Siapa yang berisiko tinggi terinfeksi virus Covid-19? & 66 & 18 & 78.6 & 21.4 \\
\hline 14. & $\begin{array}{l}\text { Kegiatan atau memisahkan orang yang tidak sakit (orang } \\
\text { sehat) yang kemungkinan sudah terinfeksi Covid-19 namun } \\
\text { gejala belum muncul, adalah pengertian dari? }\end{array}$ & 61 & 23 & 72.6 & 27.4 \\
\hline 15. & $\begin{array}{l}\text { Cairan desinfektan digunakan hanya pada permukaan benda- } \\
\text { benda dan bukan pada tubuh? }\end{array}$ & 75 & 9 & 89.3 & 10.7 \\
\hline 16. & $\begin{array}{l}\text { Gejala pilek, hidung tersumbat, bersin dan sakit kepala bukan } \\
\text { gejala pada orang yang terinfeksi virus Covid-19? }\end{array}$ & 62 & 22 & 73.8 & 26.2 \\
\hline 17. & $\begin{array}{l}\text { Tindakan yang terpisah secara fisik dengan mengatur jarak dari } \\
\text { orang lain setidak nya } 1 \mathrm{~m} \text {, adalah pengetian dari? }\end{array}$ & 79 & 5 & 94.0 & 6.0 \\
\hline 18. & $\begin{array}{l}\text { Saat ini tidak ada obat yang efektif untuk Covid-2019, tetapi } \\
\text { pengobatan simtomatik dan suportif dini dapat membantu } \\
\text { sebagian besar pasien pulih dari infeksi? }\end{array}$ & 48 & 36 & 57.1 & 42.9 \\
\hline 19. & $\begin{array}{l}\text { Orang yang memiliki kontak dengan seseorang yang terinfeksi } \\
\text { virus Covid-19 harus segera diisolasi di tempat yang tepat. } \\
\text { Dengan periode pengamatan adalah } 30 \text { hari? }\end{array}$ & 52 & 32 & 61.9 & 38.1 \\
\hline 20. & $\begin{array}{l}\text { Memisahkan orang yang sakit dengan gejala Covid-19 dan } \\
\text { mungkin menular untuk mencegah penyebaran penyakit, } \\
\text { adalah pengertian dari? }\end{array}$ & 57 & 27 & 67.9 & 32.1 \\
\hline
\end{tabular}


Faletehan Health Journal, 8 (1) (2021) 42-50 www. journal.Ippm-stikesfa.ac.id/ojs/index.php/FHJ ISSN 2088-673X | 2597-8667

Tabel 5. Distribusi Frekuensi Kuesioner Sikap Responden di Lingkungan Perumahan Taman Banten Lestari RW.21

\begin{tabular}{|c|c|c|c|c|c|c|c|c|c|}
\hline \multirow{2}{*}{ No } & \multirow{2}{*}{ Kuesioner Sikap } & \multicolumn{2}{|c|}{ SS } & \multicolumn{2}{|c|}{$\mathbf{S}$} & \multicolumn{2}{|c|}{ TS } & \multicolumn{2}{|c|}{ STS } \\
\hline & & $\mathbf{F}$ & $\%$ & $\mathbf{F}$ & $\%$ & $\mathbf{F}$ & $\%$ & $\mathbf{F}$ & $\%$ \\
\hline 1. & $\begin{array}{l}\text { Sosial distancing merupakan pencegahan dari } \\
\text { Covid-19 }\end{array}$ & 0 & 00.0 & 0 & 00.0 & 34 & 40.5 & 50 & 59.5 \\
\hline 2. & $\begin{array}{l}\text { Cuci tangan sangat efektif terhadap } \\
\text { pencegahan Covid-19 }\end{array}$ & 0 & 00.0 & 1 & 1.2 & 33 & 30.3 & 50 & 59.5 \\
\hline 3. & $\begin{array}{l}\text { Saat sedang batuk/bersin segera ditutup } \\
\text { dengan tisu atau pun siku baju }\end{array}$ & 58 & 69.0 & 25 & 29.8 & 1 & 1.2 & 0 & 00.0 \\
\hline 4. & $\begin{array}{l}\text { Tidak meberikan ijin kepada anak untuk } \\
\text { keluar bermain bersama teman saat sedang } \\
\text { lockdown }\end{array}$ & 43 & 51.2 & 40 & 47.6 & 1 & 1.2 & 0 & 00.0 \\
\hline 5. & $\begin{array}{l}\text { Mendapatkan informasi mengenai covid-19 } \\
\text { hanya dari sumber resmi. Seperti Kemenkes, } \\
\text { Dinkes, WHO, Unicef. }\end{array}$ & 40 & 47.6 & 43 & 51.2 & 1 & 1.2 & 0 & 00.0 \\
\hline 6. & $\begin{array}{l}\text { Membersihkan virus yang menempel di } \\
\text { permukaan benda seperti meja, gagang pintu } \\
\text { atau saklar lampu yang kerap disentuh orang } \\
\text { dengan cairan desinfektan }\end{array}$ & 26 & 31.0 & 43 & 51.2 & 8 & 9.5 & 7 & 8.3 \\
\hline 7. & $\begin{array}{l}\text { Berjemur dan berolahraga dengan mengatur } \\
\text { jarak dengan orang lain dapat menghindari } \\
\text { penyebaran Covid-19 }\end{array}$ & 15 & 17.9 & 33 & 39.3 & 31 & 36.9 & 5 & 6.0 \\
\hline 8. & $\begin{array}{l}\text { Melakukan cuci tangan ketika hendak ingin } \\
\text { makan saja }\end{array}$ & 0 & 00.0 & 2 & 2.4 & 44 & 52.4 & 38 & 45.0 \\
\hline 9. & $\begin{array}{l}\text { Hanya orang yang lemah daya tahan } \\
\text { tubuhnya yang dapat terserang Covid- } 19\end{array}$ & 0 & 00.0 & 0 & 00.0 & 44 & 52.4 & 40 & 47.6 \\
\hline 10. & $\begin{array}{l}\text { Membiarkan anak saat libur sekolah pergi } \\
\text { keluar rumah dan bermain diluar rumah. }\end{array}$ & 0 & 00.0 & 2 & 2.4 & 25 & 29.8 & 57 & 67.9 \\
\hline 11. & $\begin{array}{l}\text { Hanya anak-anak dan lansia saja yang dapat } \\
\text { terjangkit Covid-19, orang dewasa tidak perlu } \\
\text { khawatir dan cemas. }\end{array}$ & 0 & 00.0 & 4 & 4.8 & 40 & 47.6 & 40 & 47.6 \\
\hline 12. & $\begin{array}{l}\text { Penggunaan masker tidak perlu dilakukan } \\
\text { saat berada diluar rumah }\end{array}$ & 0 & 00.0 & 7 & 8.3 & 32 & 38.1 & 45 & 53.6 \\
\hline 13. & $\begin{array}{l}\text { Informasi dari media sosial diterima langsung } \\
\text { dan disebar luaskan tanpa menyelidiki } \\
\text { kebenaraanya. }\end{array}$ & 0 & 00.0 & 1 & 1.2 & 44 & 52.4 & 39 & 46.4 \\
\hline 14. & $\begin{array}{l}\text { Tidak perlu mengikuti perkembangan } \\
\text { informasi dan tidak mematuhi nasihat dinas } \\
\text { kesehatan setempat termasuk untuk } \\
\text { pembatasan perjalanan, pergerakan dan } \\
\text { pertemuan. }\end{array}$ & 1 & 1.2 & 6 & 7.1 & 41 & 48.8 & 36 & 42.9 \\
\hline 15. & $\begin{array}{l}\text { Saat sedang sakit menunjukan gejala demam, } \\
\text { sakit tenggorokan, batuk, sesak nafas tidak } \\
\text { perlu memeriksakan diri ke fasilitas } \\
\text { pelayanan kesehatan. }\end{array}$ & 4 & 4.8 & 8 & 9.5 & 37 & 44.0 & 35 & 41.7 \\
\hline
\end{tabular}

Sumber: Data Primer, 2020

Gambaran sikap masyarakat di lingkungan Perumahan Taman Banten Lestari Tahun 2020 terlihat bahwa hampir sebagian besar masyarakat memiliki sikap positif tentang Covid-19. Sikap positif ini terlihat dari dukungan positif terhadap perilaku masyarakat yang berada di lingkungan
Perumahan Taman Banten Lestari khususnya di RW.21 yang berperan serta aktif dalam kegiatan pencegahan penularan Covid-19, kegiatan pencegahan penularan Covid-19 dengan melakukan pemasangan spanduk mengenai Covid19 , melakukan penyemprotan pada rumah-rumah 
warga dengan desinfektan, menghimbau seluruh warga untuk mengenakan masker serta melakukan pengecekan awal pada gerbang masuk lingkungan RW.21 dengan melakukan pengecekan suhu dan membersihkan tangan menggunakan handsanitizer. Terlihat pada jawaban responden dalam kuesioner sikap yang telah disebarkan oleh peneliti dengan pertanyaan favorable (positif), saat sedang batuk/bersin segera ditutup dengan tisu atau pun siku baju di dapatkan sebagian besar responden menjawab sangat setuju sebanyak 58 responden $(69,0 \%)$. Dan pada pertanyaan unfavorable (negatif), membiarkan anak saat libur sekolah pergi keluar rumah dan bermain diluar rumah di dapatkan sebagian besar responden menjawab sangat tidak setuju sebanyak 57 responden $(69,7 \%)$.

Upaya ini di dukung oleh pemerintah saat ini berdasarkan Surat Edaran Nomor Hk.02.01/Menkes/199/2020 mengenai pencegahan Covid-19 yang terdiri dari melakukan pembersihan menggunakan desinfektan minimal 3 kali sehari terutama pada waktu aktivitas padat di setiap lokasi representatif (pegangan pintu, tombol lift, pegangan eskalator, dll), deteksi suhu tubuh di setiap titik pintu masuk tempat umum dan transportasi umum, promosikan cara cuci tangan secara teratur dan menyeluruh, mensosialisasikan etika batuk/bersin di tempat umum dan transportasi umum, memperbaharui informasi tentang Covid19 secara berkala dan menempatkan di area yang mudah dilihat oleh pengunjung dan penumpang serta masyarakat dihimbau untuk melakukan isolasi diri (Kemenkes, 2020).

Sikap responden pada penelitian yang dilakukan Zhong, et al (2020) mengatakan bahwa hampir semua responden $(97,1 \%)$ memiliki sikap positif bahwa China dapat memenangkan pertempuran melawan Covid-19 dan menunjukkan bahwa masyarakat di China 3,6\% pergi ke tempattempat ramai dan 2,0\% tidak memakai masker saat meninggalkan rumah.

Sikap positif terhadap Covid-19 yang ditunjukan oleh sebagian besar masyarakat saat ini dengan melakukan tindakan pencegahan untuk mencegah infeksi oleh Covid-19: tidak pergi ke tempat-tempat ramai dan mengenakan masker ketika pergi ke luar. Tindakan ini di perketat dengan diterapkan nya oleh pemerintah untuk melarang pertemuan publik, serta untuk menghindari tingginya infeksi virus Covid-19 yang dapat dengan mudah di tularkan di antara orang- orang melalui tetesan pernapasan yang tidak terlihat (Zhong et al, 2020). Temuan ini jelas menunjukkan pentingnya meningkatkan pengetahuan masyarakat megenai Covid-19, yang nantinya akan berdampak juga pada peningkatan sikap dan praktik masyarakat terhadap Covid-19. Kurangnya kesadaran sering mengarah pada sikap yang tidak peduli, yang dapat mempengaruhi kesiapan untuk menghadapi tantangan-tantangan ini.

3. Distribusi Frekuensi Tingkat Kecemasan Masyarakat Tentang Covid-19 di Lingkungan Perumahan Taman Banten Lestari RW.21 Tahun 2020

Tabel 6. Distribusi Frekuensi Berdasarkan Tingkat Kecemasan Responden di Lingkungan Perumahan Taman Banten Lestari RW.21

\begin{tabular}{lcc}
\hline \multicolumn{1}{c}{ Tingkat Kecemasan } & f & $\mathbf{\%}$ \\
\hline Berat & 0 & 0 \\
\hline Sedang & 12 & 14,3 \\
\hline Ringan & 57 & 67,9 \\
\hline Tidak ada & 15 & 17,9 \\
\hline Total & 84 & 100 \\
\hline
\end{tabular}

Sumber: Data Primer, 2020

Berdasarkan tabel 3 di atas hasil analisa univariat berdasarkan karakteristik tingkat kecemasan responden dari total 84 responden di peroleh data sebagian besar masyarakat yang memiliki kecemasan ringan mengenai kejadian Covid-19 sebanyak 57 responden (67,9\%). Penentuan tingkat kecemasan responden diambil berdasarkan kuesioner yang sudah baku yaitu HARS (Hamilton Anxiety Rating Scale). Skor > 27 kecemasan berat, skor 15-27 kecemasan sedang, skor 6-14 kecemasan ringan, skor $<6$ tidak ada kecemasan.

Tingkat kecemasan masyarakat di lingkungan Perumahan Taman Banten Lesatari Tahun 2020, bahwa sebagian besar masyarakat memiliki kecemasan ringan. Tingkat kecemasan ringan ini disebabkan karena masyarakat di lingkungan Perumahan Taman Banten Lestari khusus nya di RW.21 sudah memanfaatkan berbagai sumber informasi untuk mendapatkan informasi mengenai Covid-19 yang sedang terjadi saat ini. Dapat lihat dari hasil penelitian yang dilakukan di lingkungan Perumahan Taman Banten Lestari Tahun 2020 mengenai sumber informasi, didapatkan hampir sebagian besar responden sebanyak $43(51,2 \%)$ 
Faletehan Health Journal, 8 (1) (2021) 42-50

responden memperoleh informasi dari media sosial.

Penyakit Covid-19 yang beredar saat ini menyerang manusia sudah banyak ditemukan dan jumlah nya terus bertambah setiap hari nya. Saat ini media sosial menjadi sumber informasi yang paling banyak digunakan responden dalam memahami penyakit Covid-19. Media sosial yang digunakan oleh masyarakat pada penelitian ini adalah facebook, whatsapp, twitter, karena seiring dengan berkembanganya teknologi, maka mengakses hal apapun akan semakin mudah menggunakan internet, jangkauan untuk mencapai informasinya pun sangat luas (Lin, 2020). Hal ini didukung dengan alasan masyarakat di lingkungan Perumhan Taman Banten Lestari yang menggunakan internet melalui smartphone sebagai media informasi dalam menggali pemahaman tentang kejadian Covid-19, karna lebih mudah dan efisien. Namun masyarakat juga merasa khawatir untuk berita berita yang masih simpang siur (hoaxs) yang beredar selama pandemi yang sedang berlangsung.

Tingkat kecemasan pada penelitian yang dilakukan oleh Roy, Savordaya, Sujita, Nivedita, Sudir dan Vikas (2020) mengatakan bahwa lebih dari dua pertiga responden melaporkan diri mereka khawatir setelah melihat berita tentang pandemi Covid-19 di berbagai platform media sosial dan sekitar $46 \%$ peserta melaporkan kekhawatiran mereka terkait dengan diskusi pandemi Covid-19 di saluran berita dan media cetak selama seminggu terakhir. Ini menunjukkan bahwa sebagian besar responden dalam penelitian memiliki kesadaran tentang infeksi Covid-19 dengan memperoleh informasi dari berbagai media.

Media memengaruhi kesehatan mental dan menambah tingkat kecemasan. Sama hal nya dengan pandemi flu babi yang terjadi di tahun 2009-2010, yang mengakibatkan kematian tinggi di seluruh dunia juga menarik perhatian media global dan meningkatkan kecemasan di kalangan publik secara signifikan (Everts, 2013). Oleh karena itu, penting untuk mengatasi kesulitan kesehatan mental dalam situasi pandemi. Demikian pula, perubahan tambahan seperti - isolasi, jarak sosial, karantina, pembatasan perjalanan dan desasdesus yang menyebar di media sosial juga cenderung mempengaruhi kesehatan mental secara negatif (Banerjee, 2020).

Ketika kecemasan memengaruhi populasi yang lebih besar, hal itu dapat menyebabkan keterbatasan dalam kegiatan sehari-hari, perilaku menghindar yang menyebabkan sosialisasi terbatas. Karena kecemasan, orang-orang mengadopsi berbagai gaya hidup dan modifikasi diet yang tidak diinginkan di bawah pengaruh rumor yang beredar (Roy, Savordaya, Sujita, Nivedita, Sudir dan Vikas, 2020).

Kecemasan dan kekhawatiran seperti itu dapat meningkat karena kesalahan persepsi di masyarakat, ketakutan dan stigma terhadap epidemi Covid-19 dapat menyebabkan konsekuensi negatif dari pengendalian penyakit. Hal ini di dukung oleh penelitian yang di lakukan oleh Lin (2020) mengatakan bahwa Untuk merancang program antistigma efektif yang mematahkan salah persepsi dalam Covid-19, dengan meningkatkan pengetahuan publik dalam Covid-19, dan menyebarkan pesan-pesan yang positif dan mendukung. Program seperti itu dapat dirancang dengan menggunakan media sosial, mengingat tingkat akses yang tinggi di media sosial.

Dengan informasi dan pengetahuan yang benar diposting di media sosial, di harapkan rasa takut dan stigma masyarakat dapat diturunkan. Dengan mendorong penyedia layanan kesehatan yang baik.

\section{Simpulan}

Berdasarkan penelitian yang telah dilakukan terhadap masyarakat yang berada di lingkungan Perumahan Taman Banten Lestari RW.21 Tahun 2020, didapatkan hasil berupa hampir sebagian besar masyarakat memiliki pengetahuan baik tentang Covid-19, hampir sebagian besar masyarakat memiliki sikap positif tentang Covid19, dan sebagian besar masyarakat memiliki tingkat kecemasan ringan tentang Covid-19.

\section{Referensi}

Adhikari, S. P., Meng, S., Wu, Y., Zhou, H. (2020) Epidemiology, Causes, Clinical Manifestation And Diagnosis, Prevention And Control Of Coronavirus Disease (COVID-19) During The Early Outbreak Period: A Scoping Review. Infectious

Diseases of Poverty (2020) 9:2. https://doi.org/10.1186/s40249-02000646-X

Banerjee, D., (2020) The COVID-19 Outbreak: Crucial Role The Psychiatrists Can Play. Asian Journal Psychiatry 102014. https://doi.org/10.1016/j.ajp.2020.102014 
Dinkes Provinsi Banten. (2020) Info Coronavirus

Provinsi Banten. Banten : Dinkes Provinsi Banten.

Everts, J., (2013) Announcing Swine Flu And The Interpretation Of Pandemic Anxiety. Antipode 45, 809-825. https://doi.org/10.1111/j.14678330.2012.01021.x

Hamilton, M. (1959) The Assesment Of Anxiety States By Rating. British Journal of Medical Psychology, 32(1), 50-5. DOI : 10.1111/j.2044-8341.1959.tb00467.x

Ika. (2020) Cara Atasi Stres Selama Pandemi COVID-19. Universitas Gajah Mada. Diakses pada tanggal 18 April. https://ugm.ac.id/id/berita/19150- caraatasi-stres-selama- pandemi-covid-19

Kemenkes RI. (2020) Frequently Asked Questions (FAQ) COVID-19 per 6 Maret 2020. Jakarta : Kementerian Kesehatan RI .(2020) Pedoman kesiapsiagaan menghadapi infeksi Novel Coronavirus (2019-nCoV). Jakarta : Kemenkes RI .(2020) Surat Edaran Tentang Komunikasi Penanganan CoronavirusDisease 2019 (Covid-19). Di akses pada tanggal 24 Maret https://www.kemkes.go.id/resources/dow nload/pengumuman/SE\%20Men kes\%20\%20Komunikasi\%20Covid-19.pdf . (2020) Infografis COVID-19 (25 April 2020). Di akses pada tanggal 25 April https://www.covid19.go.id/2020/04/25/inf ografis-covid- 19-25-april-2020/

KOMINFO. (2020) Isu Hoaks Corona Virus. Jakarta : Kementrian Komunikasi dan Informatika RI

Lee, C.H. (2020) Role of dermatologists in the uprising of the novel corona virus (COVID19): Perspectives and opportunities. Dermatol Sin 2020;38:1-2. DOI:n 10.4103/ds.ds_5_20

Li, Q., Guan, X., Wu, P., ............. Feng, Z. (2020) Early Transmission Dynamics In Wuhan, China, Of Novel CoronavirusInfected Pneumonia. The New England Journal of Medicin published on January 29, 2020, at NEJM.org.DOI: 10.1056/NEJMoa2001316

Lin, C.Y. (2020) Social reaction toward the 2019 novel coronavirus (COVID-19). Soc Health Behav 2020;3:1-2. DOI: 10.4103/SHB.SHB_11_20
Liu, Z., Pierre, M., Ousmane, S., \& Glenn, W. (2020). Understanding Unreported Cases in the COVID-19 Epidemic Outbreak in Wuhan, China, and the Importance of Major Public Health Interventions. Biology 2020, 9, 50. http://dx.doi.org/10.3390/biology9030050

Rahma, S.S., Kuswandewi, M., dan Chrysanti, M. (2016) Gambaran Pengetahuan Masyarakat mengenai Influenza pada Manusia di Kabupaten Indramayu dan Majalengka sebagai Wilayah Kejadian Luar Biasa H5N1 pada Unggas di Jawa Barat. JSK, Volume 1 Nomor 3 Tahun 2016.

Roy, D., Sarvodaya, T., Sujita, K.K., Nivedita, S., Sudhir, K.V., dan Vikas K. (2020) Study Of Knowledge, Attitude, Anxiety And Perceived Mental Healthcare Need In Indian Population During Covid-19 Pandemic. Asian Journal of Psychiatry 102083. https://doi.org/10.1016/j.ajp.2020.102083

Ryalino C. (2020) Covid-19: What We Know So Far. Bali Journal of Anaesthesiol 2020;4:1-

2. DOI: 10.4103/BJOA.BJOA_17_20

Sari, D.P., Nabila, S. dan Atiqoh. (2020) Hubungan Antara Pengetahuan Masyarakat Dengan Kepatuhan Penggunaan Masker Sebagai Upaya Pencegahan Penyakit Covid-19 Di Ngronggah. Jurnal Ilmiah Rekam Medis dan Informatika Kesehatan (INFOKES), VOL 10 No. 1, Februari 2020 ISSN : 2086 - 262.

WHO. (2020) Clinical Management Of Severe Acute Respiratory Infection When Novel Coronavirus (2019-Ncov) Infection Is Suspected. Interim Guidance. Diakses pada tanggal 25 Maret. https://www.who.int/publicationsdetail/clinical-management-of-severeacute-respiratory-infection-when- novelcoronavirus-(ncov)-infection-is-suspected

Zhong, B.L., Wei, L., Li, H.M., ................ Li, Y. (2020) Knowledge, Attitudes, And Practices Towards COVID-19 Among Chinese Residents During The Rapid Rise Period Of The COVID-19 Outbreak: A Quick Online Cross-Sectional Survey. International Journal of Biological Sciences 2020 Vol. 16(10): $\quad$ 1745-1752. DOI: 10.7150/ijbs.45221. 